\title{
Understanding the Livelihood Characteristics of the Migratory and Non-Migratory Fishers of the Padma River, Bangladesh
}

\author{
M. I. Khan ${ }^{1,2 *}$, M. M. Islam ${ }^{1}$, G. K. Kundu ${ }^{1,3}$, M. S. Akter ${ }^{1}$ \\ ${ }^{1}$ Department of Fisheries, University of Dhaka, Dhaka-1000, Bangladesh \\ ${ }^{2}$ Graduate School of World Fisheries University, 45 Yongso-ro, Nam-gu, Busan 49513, Republic of Korea \\ ${ }^{3}$ School of Earth Sciences and Environmental Engineering, Gwangju Institute of Science and \\ Technology, Republic of Korea
}

Received 8 November 2017, accepted in final revised form 7 March 2018

\begin{abstract}
The Padma is the second longest and one of the trans-boundary rivers of Bangladesh that significantly contributes to fisheries production and supports the fishers' livelihoods. This study assesses the livelihood characteristics of the Padma river-dependent migratory and non-migratory fishers, employing household interviews, focus group discussions (FGDs), and key informant interviews from July to October, 2015. All migratory fishers were fulltime fishers, whereas, non-migratory fishers included full time $(88.89 \%)$, part-time and occasional fishers $(11.11 \%)$. Maximum fishers were belonging to the age group of 31 to 50 years of which $94.74 \%$ were migratory and $57.4 \%$ were non-migratory fishers. Half of the migratory and non-migratory fishers were illiterate. $89.47 \%$ migratory fishers used river water for drinking and other purposes, whereas, $94.44 \%$ non-migratory fishers used tubewell water. Average annual incomes of both migratory (58\%) and non-migratory (65\%) fishers ranged from Tk. 30,000 to 60,000 , whereas $26 \%$ migratory and 5\% non-migratory fishers had average annual incomes above Tk. 60,000. The overall livelihood status of the migratory and non-migratory fishers was not satisfactory as they have faced problems like conflicts with elite groups for resources, lack of fish preservation facilities. Effective initiatives and their proper implementations are very crucial to develop the Padma river fisher's livelihood conditions.
\end{abstract}

Keywords: Migratory and non-migratory fishers; Livelihood; Padma river; Bangladesh.

(C) 2018 JSR Publications. ISSN: 2070-0237 (Print); 2070-0245 (Online). All rights reserved. doi: http://dx.doi.org/10.3329/jsr.v10i3.34492

J. Sci. Res. 10 (3), 261-273 (2018)

\section{Introduction}

Bangladesh is the world's $4^{\text {th }}$ largest inland waters capture fisheries producing country [1] where rivers are considered as common pool resources (CPR) for the livelihoods of millions of fishers directly and indirectly [2]. Fisheries are often available in remote and

*Corresponding author: makidu107@gmail.com 
rural areas where other economic activities are limited and can thus play important roles for food supply, food security and income generation all over the country from local to national levels. This sector contributes $22.60 \%$ to agricultural sectors, $3.69 \%$ to Gross Domestic Product (GDP) and $2.01 \%$ to total export earnings, and provides $60 \%$ of nation's animal protein intake and supports 7.8 million people's livelihoods (more than $11 \%$ of the total population) directly and indirectly [2]. The Padma is one of the transboundary rivers that crosses through Bangladesh and India. In 2016-17, total 6,512 metric ton (MT) fish were harvested from the Padma river which was $3.65 \%$ of the total fish captured from all the rivers in Bangladesh [3]. As well as total 2,086 kg carp hatchling were collected from the river in 2017 , and it was $41.17 \%$ of the total natural hatchling production in all the rivers of Bangladesh [3]. In 2016-17, about 1,168 MT fish were caught from the Padma river in Manikganj district among the total fish catch from the Padma river [3] but it was 762 MT in 2015-16 [4].

The term fishing clearly refers to catching activities, which means all activities aiming at extracting wild fish from open waters (natural waters), as opposed to the rearing of aquatic animals in controlled environments and with human intervention (stocking, feeding, etc.). Fishing for commercial purposes means to sell fish in domestic and export markets but not for recreational purposes. Fishing is not just a livelihood activity but a way of life which determines social identity and relationships [5]. As the fishers solely dependent on fishing for their income and nutrition, so their income varies with their capability and quantity of the capturing fish. The fishers can be classified into three groups depending on time involvement in fishing, such as full-time (9-12 months per annum), part-time (3-9 months per annum) and occasional (less than 3 months per annum) [6]. While for the full-time group, fisheries are the sole source of their livelihoods, for part-time and occasional groups, fisheries form part of their diversified livelihood strategy [7].

Fishers not only fish around or close to their locality but also sometimes migrate to other areas to carry out their activities. These include temporary or permanent movement of fisher folk, fish processors, fish traders and fisheries workers from one defined location to another destination, as a result of shifts in natural resource availability [8]. This migration is due to various reasons, such as favorable climate, better food supply, profitable employment, availability of water for fishing, riverbank erosion, drought, lack of a job in particular season, etc. [9]. Migration is common among the people who are dependent on natural resources for their livelihoods [10]. According to Chambers and Conway [11], a livelihood can be defined as the capabilities, assets and activities required for means of living and it will be only sustainable when it can cope with and recover from shocks and stresses or enhance its capabilities and assets, while not undermining the natural resource base. The livelihood assets such as human, physical, natural, financial and social capital that form the building block of livelihoods are affected by the shocks and stresses [12]. Sustainable livelihoods and development are the pre-requisites factor for achieving the Millennium Development Goals (MDGs). For the development of the economically backward sector, information about fishers of a particular region is 
imperative and decisive [13]. Lack of sufficient and authentic information on the livelihood characteristics of the target population is one of the serious impediments to the successful implementation of the developmental program.

Fishers are amongst the most vulnerable communities in Bangladesh. Due to several factors (e.g. economic, social and technical constraints), the fishers cannot catch fish properly. As a result, they are not capable to earn sufficient amount of money to meet basic needs [14], and they live hand to mouth and are considered as the poorest of the poor [15]. Thus, the available natural resources are exploited by the poor fishing communities to support their livelihoods. Rahman et al. [15], and Faruque and Ahsan [16] reported that fishers' livelihoods have been deprived by inadequate credit availability, lack of fish preservation facilities, etc. Although the Padma fisheries are playing a significant role in country's economy as we discussed above, but there is no systematic research on the livelihood characteristics of the migratory and non-migratory fishers of this river. Considering the above facts, the present study was carried out to assess the livelihood characteristics of the migratory and non-migratory fishers of the Padma river.

\section{Methods}

This study was conducted in two different villages, namely Andharmanik under Boyra union and Dhulsura under Dhulsura union in Harirampur Upazila, Manikganj (Fig. 1) from July to October, 2015. These villages were selected as they are located on the bank of the Padma river, which is the main source of fishing for the fishers.

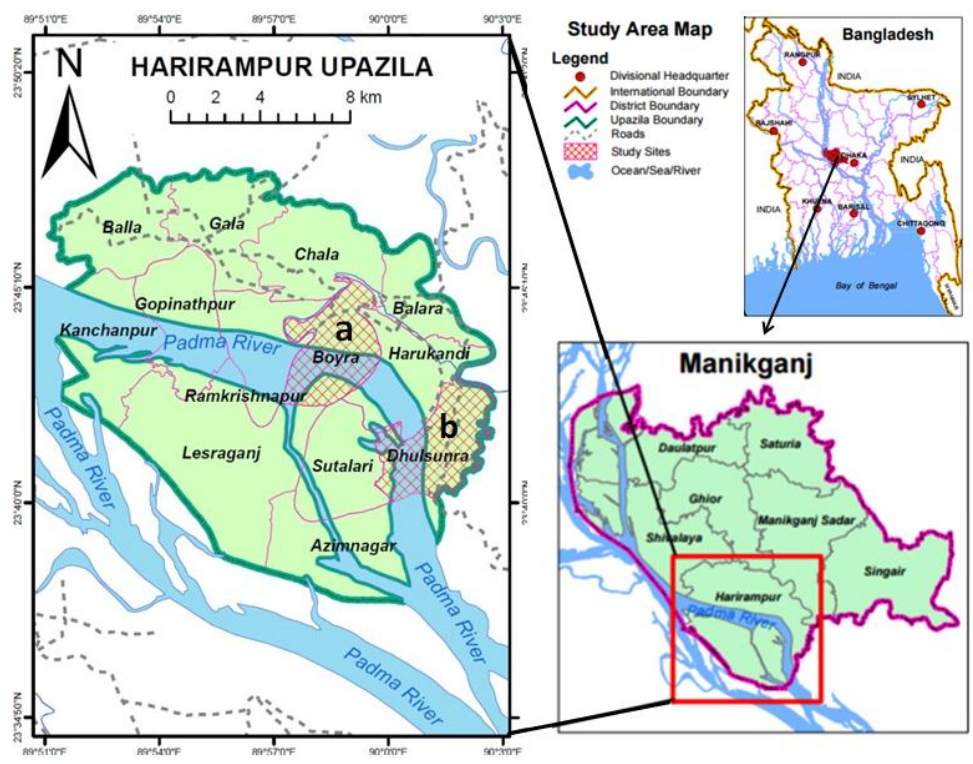

Fig. 1. Map of the study sites under Harirampur Upazila: a) Andharmanik within Boyra union and b) Dhulsura within Dhulsura union. 
The study was based on primary data that were collected through mixed method approaches (e.g., semi-structured interview, focus group discussions (FGDs) and key informants interviews). At first, a draft semi-structured questionnaire was designed following De Vaus [17]. The questionnaire was first developed in English then translated into Bangla (native language) carefully maintaining the meaning. Before collecting primary data, the questionnaires were pilot-tested with a small sample of respondents to verify the appropriateness of the questions and the wording used. Attention was given to any new information in the draft questionnaire in order to reach the study objective. The final questionnaire was improved, rearranged and modified based on the information gained through a pilot survey. The final questionnaire included the questions of the migratory and non-migratory livelihood characteristics.

Data (such as fishers type, gender, religion, age, years of education, family composition, years of involvement in fishing, annual income, etc.) were coded in a way that MS Excel (Version 2010) and Statistical Package for Social Sciences - SPSS (version 20) could understand to enable appropriate statistical analysis. Data were analyzed in SPSS using descriptive statistics in the form of frequencies and percentages. Data were presented in the form of graphs and tables to give graphical representations of the data. In this study, after analyzing all the data, results were verified by three household interviews and one FGD to entirely different fishers sample in the study area.

\section{Results and Discussion}

A total of 73 fishers from two different villages were interviewed to acquire information on various aspects of their livelihood characteristics. A detailed analysis was made on the following parameters and presented in this section.

\subsection{Fishers type}

Based on migration, fishers were categorized into two types such as migratory and nonmigratory. But depending on time involvement in fishing, they were classified into three types such as full-time, part-time and occasional. This study found from household interviews that all migratory (100\%) and most of the non-migratory fishers (88.89\%) were full-time, but there were also part-time and occasional fishers among the non-migratory (Fig. 2). Full-time fishers depend on fishing throughout the year for their livelihoods and incomes (9-12 months per annum). Part-time fishers undertake fishing during a part of the year (3-9 months per annum), mainly in the monsoon and post-monsoon seasons, supplementing their fishing income by doing farm works as laborers and driving vehicles, whereas occasional fishers are opportunistic and fish mainly for household consumption (less than 3 months per annum). They rely primarily on petty business, livestock rearing and agriculture for their livelihoods. Islam [18] categorized the above three types of fishers in the coastal area of Bangladesh. 


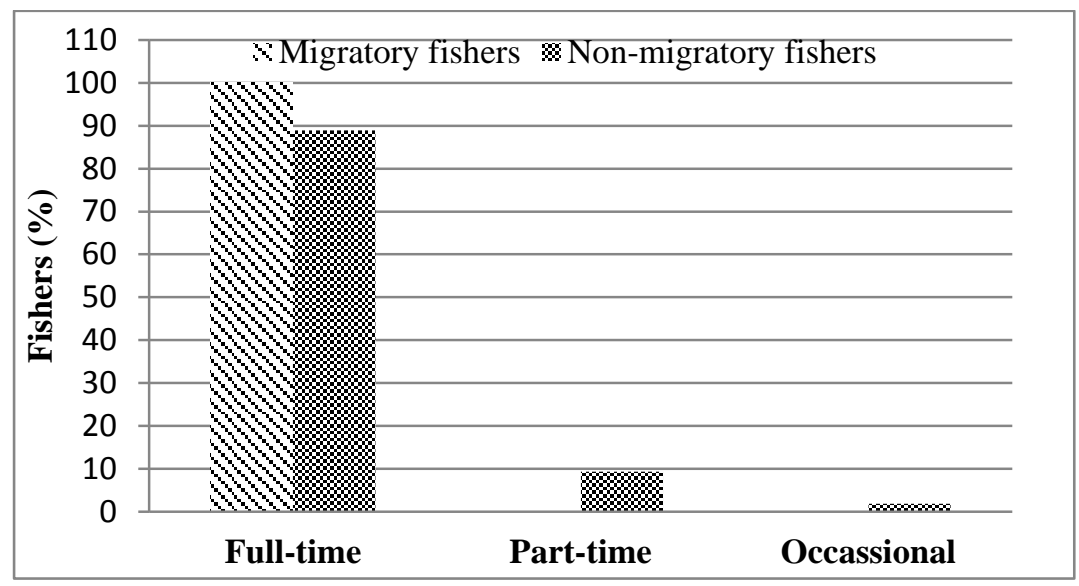

Fig. 2. Types of the migratory and non-migratory fishers in the study area.

\subsection{Gender}

In this study, no female fisher was found. The key reason for no involvement of female fishers in the Padma river fishing was social restrictions that agreed with Faruque and Ahsan [16] who studied in the same river of Rajshahi district. Ahmed et al. [19] also reported that women have less freedom both socially and economically than men that restrict their activities. Women are mainly involved in making and repairing fishing gear and post-harvest activities such as processing and small-scale marketing [20]. Sultana and Thompson [21] also reported that women are often excluded from fishing.

\subsection{Religion}

The study found that the Padma river fishing in the study sites was dominated by the Hindu fishers (average 93.15\%) followed by 6.85\% Muslims fishers (Fig. 3). This study agrees with the finding of Faruque and Ahsan [16] in Padma river, Rajshahi and Islam et al. [22] in Monirampur Upazila, Jessore. However, this study found no significant difference between the migratory and non-migratory fishers in respect of their religious status. At present the involvement of Muslims in the Padma river fishing activities are increasing continuously in the study area which was also reported by Faruque and Ahsan [16] in Rajshahi district. However, Rahman et al. [15] in Talma river, Kabir et al. [23] in old Brahmaputra river and Khan et al. [24] in Tista river reported that most of the fishers were Muslim in those respective areas. 


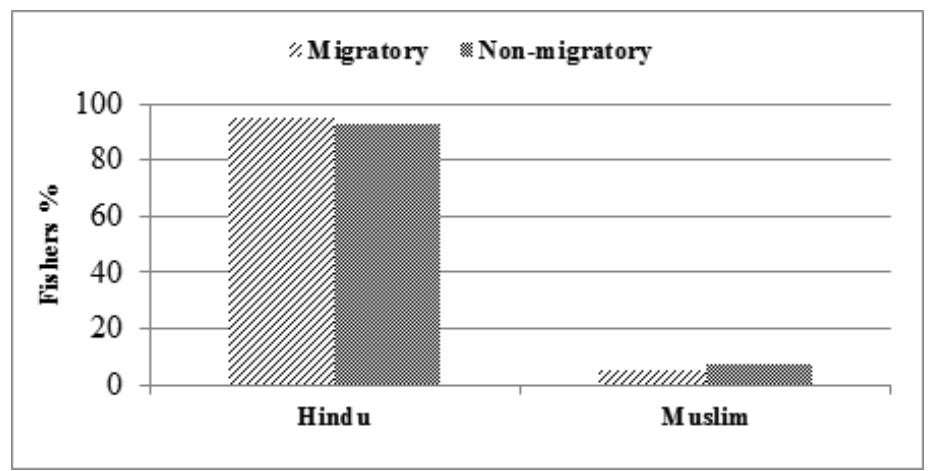

Fig. 3. Religious status of the fishers in the study area.

\subsection{Age}

The age categories of the fishers are important to understand the potential productive human resources. In this study, it was found from household interviews that most (94.74\%) of the migratory fishers of the Padma river were between 31 to 50 years old, in contrast, $57.4 \%$ non-migratory fishers were in that age categories (Fig. 4). This study also found that the percentage of young fishers of less than 30 years was very low. From FGDs, this study found that younger generation (age less than 30 years) of both migratory and non-migratory fishers lost their attention towards fishing in the Padma river due to the decreasing catch. Again various social and economic factors also influenced them. Therefore, they seek other works to support their livelihoods. Similarly, Rahman et al. [15] in Talma river of Northern part of Bangladesh, Faruque and Ahsan [16] in the Padma river, Rajshahi, Islam et al. [22] in Jessore and Kabir et al. [23] in old Brahmaputra river reported maximum fishers were in the age group of 31-40 years.

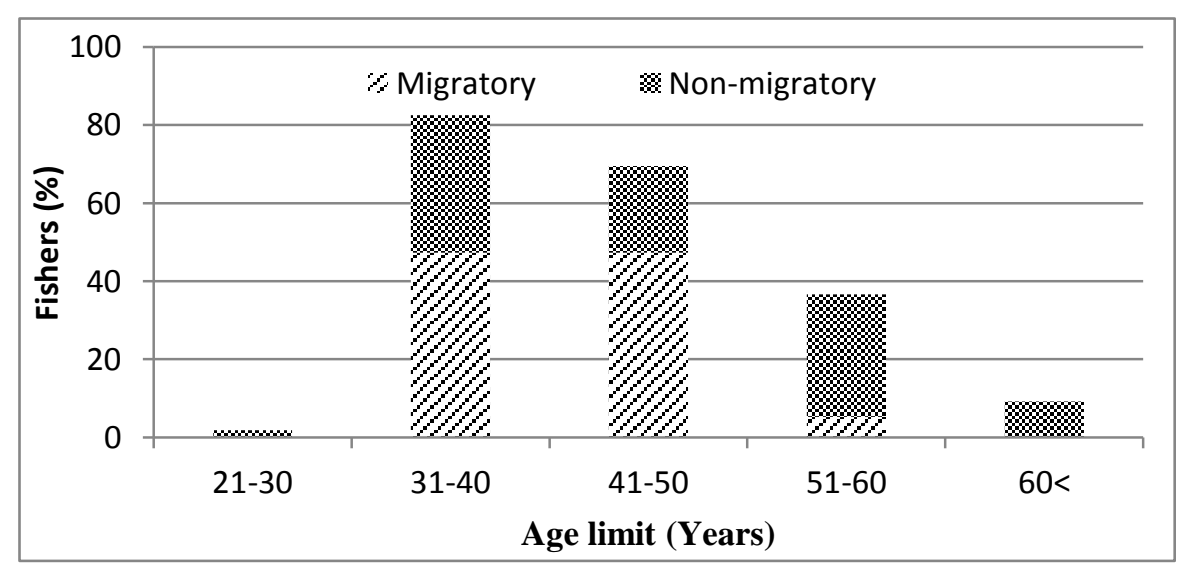

Fig. 4. Age structure of migratory and non-migratory fishers in both study sites. 


\subsection{Educational status}

This study found from household interviews that nearly half of the migratory and more than half of the non-migratory fishers in the study sites had no formal education (Fig. 5). Kabir et al. [23], Khan et al. [24] and Rahman et al. [15] reported that $88 \%$ in old Brahmaputra river, $68 \%$ in Tista river and $58 \%$ in Talma river had no education respectively. From reconnaissance study, it was found that due to the fisher's poor socioeconomic conditions, they could not get the opportunity to take education. Again they led their children involved in fishery-related activities to support their family rather than going school. This study also supports the finding of Chowdhury et al. [25] in Naaf river, Bangladesh. Education is a part of human resource development. Education enhances a person's ability to understand and manipulate critical aspects of the modern world, receive and integrate information and perceive and resolve difficult situations [26]. So, fisher's education is important to become aware and familiar with the latest technology for fishing and to become updated with the recent climatic variability and changes.

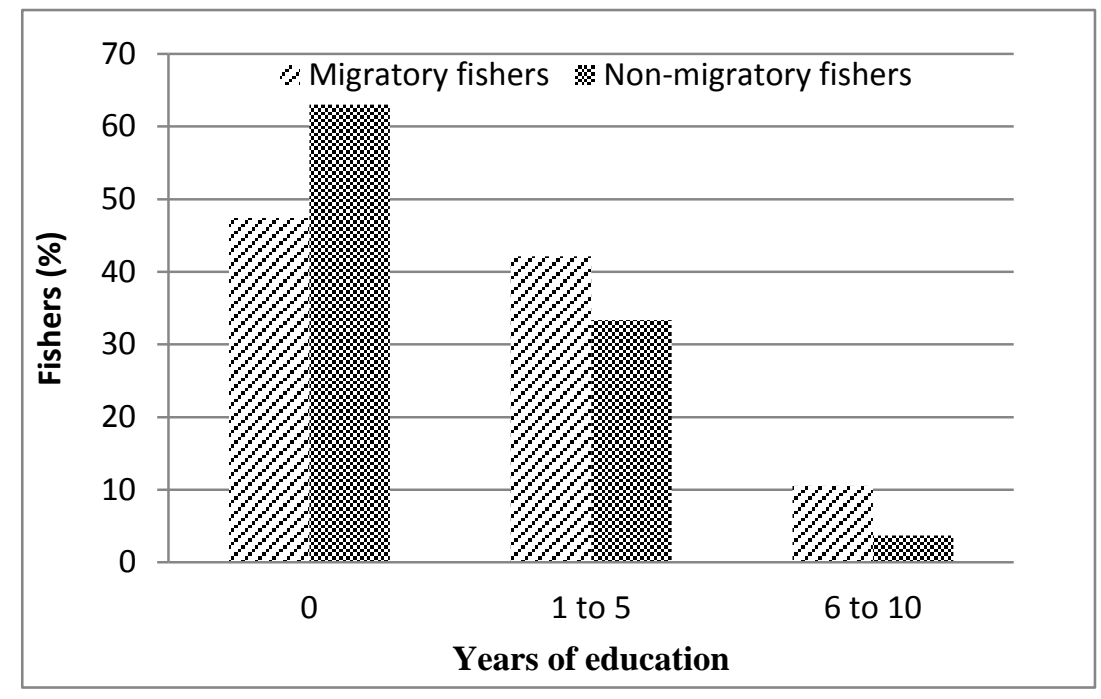

Fig. 5. Educational status of the migratory and non-migratory fishers in the study area.

\subsection{Family composition}

Family composition is defined as the number of persons, either working or not, belonging to the same family, and it is an imperative socio-economic indicator that is related to occupation and income. In fisher's family, it has an important influence on the food consumption and fishing activities. This study revealed from household interviews that the migratory and non-migratory fishers' family of the study sites was consisted of $5.23 \pm$ 2.11 members (mean \pm standard deviation). Depending on family size, this study divided fishers family into three classes such as small, medium and large. This study also showed 
that $42 \%$ migratory and $50 \%$ non-migratory fishers had 5 to 7 family members (Fig. 6), whereas, $21 \%$ and $7 \%$ families had more than 7 members respectively. Khan et al. [24] reported that 57\% fisher's family in Tista river had 5-7 members. Faruque and Ahsan [16] found only $7.92 \%$ fishers of the Padma river, Rajshahi district had 7 to 9 family members.

From this study, it was also found that the joint family structure was dominant over the nuclear family in both the migratory and non-migratory fishers (Table 1). From key informant interviews, it was found that the joint fisher's families were continuously broken because most of the fishers were economically poor and the children wanted to separate from their parents when they reach their old age. However, in case of migratory fishers, the tendency to break down joint family to nuclear family was comparatively low than non-migratory fishers. The migratory fishers believed that their large family size can support them in fishing activities as they have migrated from one area to another behind their families. Rahman et al. [15] reported that maximum fishers of Talma river of the Northern part of Bangladesh had joint families.

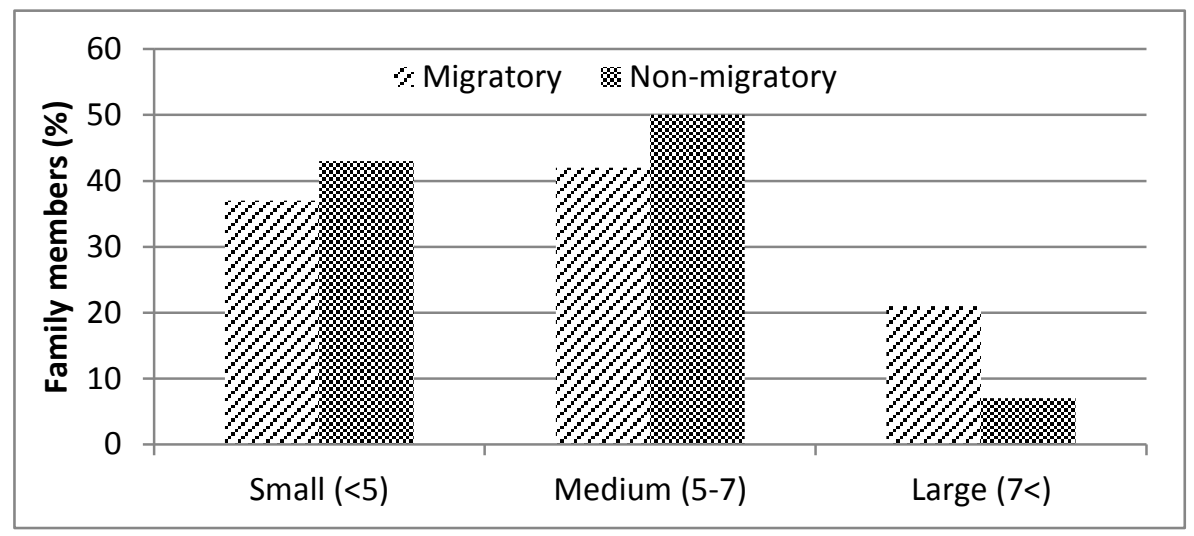

Fig. 6. Family size of the migratory and non-migratory fishers in both study sites.

Table 1. Migratory and non-migratory fisher's family type of the study sites.

\begin{tabular}{lcc}
\hline Fishers type & \multicolumn{2}{c}{ Family types (\%) } \\
\cline { 2 - 3 } & Nuclear family & Joint family \\
\hline Migratory & 37 & 63 \\
Non-migratory & 43 & 57 \\
\hline
\end{tabular}

\subsection{Years of involvement in fishing}

Years of involvement in fishing are important to develop fishing skills and to achieve practical experiences. From household interviews, this study found that $94.74 \%$ migratory fishers had 31 to 50 years of fishing experiences (Table 2). On the other hand, 57.4\% nonmigratory fishers had 31 to 50 years of fishing involvement in the Padma river. 
Table 2. Migratory and non-migratory fisher's years of fishing involvement.

\begin{tabular}{lcc}
\hline Years of fishing involvement & \multicolumn{2}{c}{ Fishers type (\%) } \\
\cline { 2 - 3 } & Migratory fishers (\%) & Non-migratory fishers (\%) \\
\hline Less than 30 & - & 1.85 \\
$31-40$ & 47.37 & 35.18 \\
$41-50$ & 47.37 & 22.22 \\
$51-60$ & 5.26 & 31.48 \\
More than 60 & - & 9.26 \\
\hline
\end{tabular}

\subsection{Income of fishers}

For a better understanding of the state of fisher's livelihoods, their income is the most important factor. In this study, fisher's income was calculated including their household expenses. This study found from household interviews that $58 \%$ migratory and $65 \%$ nonmigratory fishers (Fig. 7) of the Padma river in the study sites had an annual income of Tk. 30,000-60,000. But Faruque and Ahsan [16] reported that most of the hilsa fishers (on an average 94\%) in the Padma river of Rajshahi district had the average annual income to the range of Tk. 30, 000 to Tk. 60,000. Migratory fisher's average annual income (Tk. 43,684 ) was comparatively higher than the non-migratory fisher's annual income (Tk. $35,278)$. But neither migratory fishers nor non-migratory fishers had annual per-capita income above US\$ 1,314 (Tk. 102,026) [27]. Rahman et al. [15] and Khan et al. [23] also reported $64 \%$ fishers of Talma river and 63\% fishers of Tista river had average annual income Tk. 30,000-60,000.

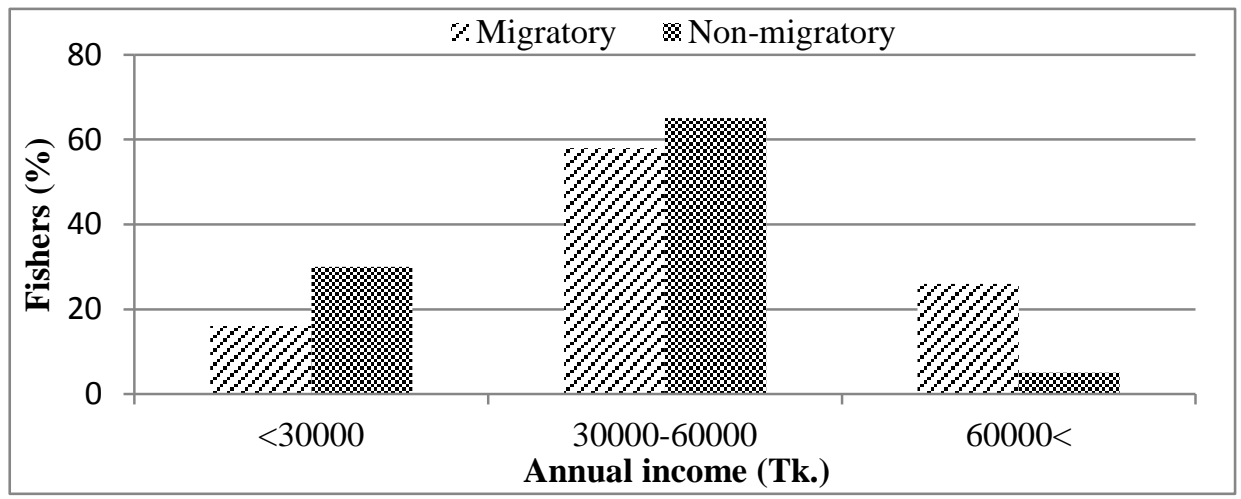

Fig. 7. Annual income (Tk.) of the migratory and non-migratory fishers in the study sites

Fisher's amount of catch varied depending on the types of nets and gears used. Again fisher's annual income varies depending on the fish size, species and quality. This study found from household interviews that seine and gill nets (such as berjal, current jal) users annual income was higher than other groups. About $26 \%$ migratory fishers had an annual income of above Tk. 60,000 (Fig. 7), since they used large seine and gill nets for fishing. The non-migratory fishers who used only cast and lift nets, their annual income was low than other fishers. 


\subsection{Sanitary facilities}

The sanitary conditions of the migratory and non-migratory fishers of the study sites were very poor. Most of the migratory fishers $(94.74 \%)$ used temporary earthen toilets (made of bamboo with leaf and inadequate drainage system nearby the Padma river) (Table 3). On the other hand, $96.3 \%$ non-migratory fishers used earthen, semi-pacca (made of tin or wood with inadequate drainage system) and pacca toilets (made of brick with cement and well drainage system). This study agrees with the findings of Faruque and Ahsan [16] and Rahman et al. [15].

Table 3. Sanitary facilities of the migratory and non-migratory fishers of the study sites.

\begin{tabular}{lcc}
\hline \multirow{2}{*}{ Types of sanitation } & \multicolumn{2}{c}{ Fishers type (\%) } \\
\cline { 2 - 3 } & Migratory fishers & Non-migratory fishers \\
\hline Earthen & 94.74 & 70.37 \\
Semi-pacca & - & 7.41 \\
Pacca & - & 18.52 \\
Open field & 5.26 & 3.70 \\
\hline
\end{tabular}

\subsection{Drinking water facilities}

The study showed that $94.44 \%$ non-migratory fishers of the Padma river of the study sites either used their own tube-wells or neighbors tube-wells as a source of water for drinking (Table 4). In contrast, only $10.53 \%$ migratory fishers of the Padma river used nearby tubewell water for drinking and other purposes, whereas, the greater proportions $(89.47 \%)$ used river water. As they are migrated from one area to another, so they are habituated or used to drink river water. But Faruque and Ahsan [16] reported that 90\% fishers of the Padma river at Godagari Upazila in Rajshahi used river water for drinking and other purposes that support the findings of this study.

Table 4. Drinking water facilities of the migratory and non-migratory fishers of the study sites.

\begin{tabular}{lcc}
\hline \multirow{2}{*}{ Sources of water } & \multicolumn{2}{c}{ Fishers type (\%) } \\
\cline { 2 - 3 } & Migratory fishers & Non-migratory fishers \\
\hline Tube-well & 10.53 & 94.44 \\
River & 89.47 & 5.56 \\
\hline
\end{tabular}

\subsection{Health facilities}

This study found that non-migratory fishers of the Padma river of the study sites took their health services from village quack doctors, Upazila health complex and local kabiraj (the person who practices Ayurveda medicine), whereas migratory fishers visited village quack doctors and Upazila health complex (Table 5). Most of the migratory (78.95\%) and non-migratory $(72.22 \%)$ fishers took their health services from the unskilled village doctors who have only limited knowledge of practical works but no knowledge of medical sciences. The study agrees with the findings of Faruque and Ahsan [16] who reported that 
most of the Padma river fishers of Rajshahi district took their health services from the unskilled non-professional village doctors. Rahman et al. [15] also reported that the Talma river fishers (64\%) got their health services from local village doctors.

Table 5. Health facilities of the migratory and non-migratory fishers of the study sites.

\begin{tabular}{lcc}
\hline \multirow{2}{*}{ Health facilities } & \multicolumn{2}{c}{ Fishers type (\%) } \\
\cline { 2 - 3 } & Migratory fishers & Non-migratory fishers \\
\hline Village doctors & 78.95 & 72.22 \\
Upazila health complex & 21.05 & 18.52 \\
Kabiraj & - & 9.26 \\
\hline
\end{tabular}

\subsection{Socio-economic constraints of the migratory and non-migratory fishers}

Both the migratory and non-migratory fishers of the Padma river of the study sites have faced some problems like conflicts with the Muslim fishers and elite groups, extortion and preservation facilities. This study reported that most of the migratory and non-migratory fishers of the Padma river of the study sites were Hindu. As it was stated earlier that the number of Muslim fishers is increasing gradually, so the migratory and non-migratory fishers have faced some conflicts with them. Faruque and Ahsan [16] also reported that the Padma river fishers have faced threats by the Muslim fishers in Rajshahi. Additionally, 85.18\% non-migratory fishers reported during FGD that some elite groups (non-professional fishers) restricted the fishing right of the non-migratory fishers in some areas of the Padma river during peak season. In that time, the elite groups hire fishers from other districts (e.g., Pabna, Jamalpur, Barisal, etc.) to fish in that areas or sometimes give the fishing right to the migratory or non-migratory fishers on some conditions (e.g., take a share on the fishers catch, demand a certain amount of money per day or month from the fishers to fish in the areas, etc.). But $57.89 \%$ migratory fishers reported that some local extortionists demand extortion from them. As more than half of the fishers had no education, so they cannot use modern technology to catch fish. Due to their poor economic condition, they co-opted their children in fishery-related activities rather send to school. Again both types of fishers reported that government supports are not sufficient enough to solve the socio-economic problems.

\section{Conclusion}

The livelihood characteristics of the migratory and non-migratory fishers of the Padma river in the study sites were not satisfactory. All the migratory and most of the nonmigratory fishers were solely dependent on fishing for their livelihoods. Due to some social and economic constraints, some of the fishers wanted to change their occupation for better living. Water resources management strategies are very important to solve the conflicts between migratory and non-migratory fishers. As well as alternative income generation activities (AIGA) could be introduced for better livelihood outcomes. Through proper education and skills development, the fishers of the Padma River could diversify their livelihood strategies by involving with others activities. The fishers should be trained 
building awareness to improve their livelihood status. Better and effective initiatives from both the government and nongovernment organizations may lead to a rapid development of the fisher's livelihood characteristics.

\section{Acknowledgments}

We are grateful to the Ministry of Science and Technology, Bangladesh for financial support. We are also grateful to all the participants for their voluntary participation.

\section{References}

1. FAO. The State of World Fisheries and Aquaculture 2014: Opportunities and Challenges. Rome: Fisheries and Aquaculture Department, Food and Agriculture Organization of the United Nations (2014).

2. DOF. National Fish Week, 2015. Compendium (In Bengali) Department of Fisheries, Ministry of Fisheries and Livestock, Bangladesh. (2015). pp. 148

3. DOF. Yearbook of Fisheries Statistics of Bangladesh 2016-17. Fisheries Resources Survey System (FRSS), Department of Fisheries, Bangladesh: Director General, DoF, 34, 129 (2017).

4. FRSS. Yearbook of Fisheries Statistics of Bangladesh. Fisheries Resources Survey System (FRSS), Department of Fisheries, Bangladesh. 33, 124 (2017).

5. S. Coulthard, D. Johnson, and J. A. Mcgregor, Glob. Environ. Chang. 21, 453 (2011). https://doi.org/10.1016/j.gloenvcha.2011.01.003

6. R. L. Welcomme, River basins, FAO Fisheries Technical Paper No. 202. Rome: Food and Agriculture Organization of the United Nations. (1983). pp. 60

7. E. H. Allison, and F. Ellis, Mar. Policy, 25, 377 (2001). doi:10.1016/S0308-597X(01)00023-9

8. S. M. Abobi and E. H. Alhassan, J. Coast. Zone Manag. 18, 395 (2015). https://doi.org/10.4172/2473-3350.1000395

9. D. Priya and S. Daniel, Seasonal migration for livelihood in India: Coping Accumulation and Exclusion. Working Paper No. 220. Overseas Development Institute (London, 2003).

10. L. M. Hunter, R. Nawrotzki, S. Leyk, G. J. Maclaurin, W. Twine, M. Collinson, and B. Erasmus, Popul. Space Place 20, 402 (2014). https://doi.org/10.1002/psp.1776

11. R. Chamber and G. C. Conway, Sustainable Livelihoods: Practical Concepts for the TwentyFirst Century, IDS Discussion Paper (1992). pp. 296. https://opendocs.ids.ac.uk/opendocs/bitstream/handle/123456789/775/Dp296.pdf?sequence=1 \&isAllowed=y (accessed February 11, 2018)

12. M. C. Badjeck, E. H. Allison, A. S. Halls, and N. K. Dulvy, Marine Policy 34, 375 (2010). https://doi.org/10.1016/j.marpol.2009.08.007

13. A. U. Ofuoku, G. N. Emah, and A. B. Itedjere, World J. Agric. Sci. 4, 558 (2008).

14. M. J. Alam, BRAC Univ. J. 2, 57 (2005).

15. M. A. Rahman, M. N. Mondal, K. A. Habib, J. Shahin, and M. G. Rabbane, Am. J. Life Sci. 3(5), 337 (2015). https://doi.org/10.11648/j.ajls.20150305.11

16. M. H. Faruque and D. A. Ahsan, World Appl. Sci. J. 32(5), 857 (2014).

17. D. A. De Vaus, Surveys in Social Science Research, $5^{\text {th }}$ Edition (Routledge, London, 2002).

18. M. M. Islam, PhD Thesis, University of Leeds, England (2013).

19. M. S. Ahmed, M. S. Alam, and H. Akther, S. Pac. Stud. 29, 1 (2009).

20. M. K. Ahmed, S. Halim, and S. Sultana, World J. Agric. Sci. 8, 253 (2012).

21. P. Sultana and P. Thompson, J. Int. Dev. 20, 53 (2008). https://doi.org/10.1002/jid.1427

22. M. R. Islam, M. N. Hoque, S. M. Galib, and M. A. Rahman, J. Fish. 1, 37 (2013).

23. K. R. Kabir, R. K. Adhikary, M. B. Hossain, and M. H. Minar, World Appl. Sci. J. 16, 869 (2012). 
24. M. R. Khan, M. I. Miah, M. B. Hossain, A. Begum, and M. H. Minar, Global Veterinaria 10, $417(2013)$

25. M. S. N. Chowdhury, M. S. Hossain, N. G. Das, and P. Barua, Mesopot. J. Mar. Sci. 26, 146 (2011).

26. J. C. Caldwell, Popul. Stud. 33, 395 (1979). https://doi.org/10.2307/2173888

27. BBS, Bangladesh Bureau of Statistics, Statistical Pocketbook Bangladesh 2015, Statistics and Informatics Division (SID), Ministry of Planning, Government of the People's Republic of Bangladesh (Dhaka, Bangladesh, 2016). 